Marie Bergström

\title{
Casual dating online. Sexual norms and practices on French heterosexual dating sites
}

\section{Online-Dating für gelegentliche Treffen. Sexuelle Normen und Praktiken in französischen heterosexuellen Partnerschaftsbörsen}

\begin{abstract}
:
Although Internet-mediated casual encounters between gay men have become an established object of study in social science, research on heterosexual online dating is largely focused on the search for romantic long-term relationships. This article presents an investigation of the new "sexual territory" that appears with heterosexual dating sites. Based primarily on qualitative fieldwork, this study first reveals the normative framework that structures the field of French dating platforms, and secondly shows how meeting online comes with a new dating scenario that tends to facilitate the engagement in short-term sexual relationships.
\end{abstract}

Key words: sexual territories, online dating, heterosexuality, casual dating.

\section{Zusammenfassung:}

Während über das Internet vermittelte gelegentliche Treffen zwischen homosexuellen Männern bereits ein etablierter Forschungsgegenstand in den Sozialwissenschaften sind, ist die Forschung zu heterosexuellem Online-Dating größtenteils auf die Suche nach romantischen Langzeitbeziehungen fokussiert. Der vorliegende Artikel will damit beginnen, diese Forschungslücke zu füllen, indem er den möglichen neuen sexuellen Bereich untersucht, der durch heterosexuelle Online-Dating-Plattformen entsteht. Diese Studie basiert hauptsächlich auf qualitativen Feldstudien und zeigt den normativen Rahmen auf, der das Feld der französischen Dating-Seiten strukturiert. Außerdem zeigt die Untersuchung, wie das Kennenlernen im Internet ein neues Dating-Szenario mit sich bringt, das dazu tendiert, die Aufnahme sexueller Kurzzeitbeziehungen zu vereinfachen.

Schlagwörter: sexuelle Bereiche, Online-Dating, Heterosexualität, sexuelle Beziehungen

\section{Introduction}

The use of online dating sites is today a widely spread social practice in the Western world and beyond (Bajos/Bozon 2008; Brym/Lenton 2001; Daneback 2006; Hogan et al. 2011; Madden/Lenhart 2006; Schulz et al. 2008). In France, which is the focus of this article, 13 percent of men and 10 percent of women have at some point logged on to such an Internet site, according to a survey conducted in 2006 (Bajos/Bozon 2008). As sug- 
gested by the authors, it is highly probable that the frequency of usage has considerably increased in the population since the survey's publication and that theses figures therefore give an underestimated picture of today's reality of French online dating.

Henceforth an important social arena for initiating intimate relationships ${ }^{1}$, online dating has become the object of a new field of research in social science. However, a glance at the scientific literature in this area reveals two separate bodies of work with few links to each other. On the one hand, one observes a relatively comprehensive literature in sociology and social psychology on dating sites as a meeting place for heterosexual individuals in search of romantic long-term relationships (Dutton et al. 2008; Ellison et al. 2006; Fiore/Donath 2004; Illouz 2006; Whitty 2007). On the other hand, Internet use by men who seek sexual encounters with other men is a major topic in research on public health and more specifically on sexual risk behaviour (Benotsch et al. 2002; Davis et al. 2006; Engler et al. 2007; Tikkanen/Ross 2003; Weatherburn et al. 2003). As an effect of the separation of academic disciplines (and their different sources of funding) as well as of diverging research interests, one observes a scientific reproduction of the common opposition between conjugal heterosexuality on one side and gay sexual relations on the other. As the study of online dating is becoming an established field of research, it appears important to go beyond this stereotypical limitation of the objects of study and to investigate the diversity of actors and practices associated with this increasingly important social phenomenon. In particular, the sexual dimension of heterosexual online dating is poorly explored and merits further attention ${ }^{2}$. Drawing on findings from the literature on gay men's sexual use of the Internet, the goal of this article is to begin to fill this academic void. More specifically, we seek to understand to what extent heterosexual dating sites constitute a new "sexual territory" - a privileged social space for engaging in, or negotiating, sexual relations (cf. Deschamps/Gaissad, 2008; Léobon/Frigault 2004) - and how "casual dating" is thus organised in this new online environment.

\section{Online dating and stigmatised sexual practices}

The studies on online dating focusing on men having sex with men (MSM) present similar results. Firstly, the Internet stands out as an important place for meeting sexual partners (Bajos/Bozon 2008; Bolding et al. 2005; Liau et al. 2006; Velter 2004). In France, 41.6 percent of the bi- and homosexual men have had sexual relations with a partner whom they had met online (Bajos/Bozon 2008). Secondly, compared to offline-dating contexts, the characteristics of the online environment facilitate the engagement in this type of relationship. Drawing

1 Relation, relationship and couple do not only refer to romantic long-term relationships but are in this article used as general terms with no regard to the temporality of the relation. Thus, they also include occasional encounters and mere sexual partners.

2 Far from being a question limited to research on online dating, Catherine Deschamps and Laurent Gaissad point out that "social science admits and comments on men's experiences of occasional encounter in all its different forms and especially same-sex relations. But within this field of research, heterosexuality is still a blind spot (non-lieu), especially that of women” (Deschamps/Gaissad, 2008: 20) (translation by the author of the article). It should also be noted that studies on romantic and sexual relationships between women are almost nonexistent in the field of online dating research and largely underdeveloped in sociology in general. 
on Al Cooper's “triple A engine” (Cooper 1998), several studies support that the accessibility, affordability and anonymity of the Internet makes it a particularly favourable context for initiating sexual contact (Léobon/Frigault 2004; Ross 2005; Tikkanen/Ross 2003). Going along the same lines, Alain Léobon and Louis-Robert Frigault (2008: 88) put forth that "as a free and unrestrained [non contraint] environment, the Internet, accessed most often from home, is perceived as more secure by its users to the extent that their social network has no possibility of judging their intentions (in particular sexual). In escaping the normative pressure that aims at socially regulating sexuality, the Internet favours the expression of diverse sexualities between men". 3

Although the literature on Internet use among men who have sex with men strongly supports that the online environment tends to facilitate sexual contacts, few studies have explored this aspect with regard to the heterosexual population. The first aim of this article is thus to investigate to what extent French heterosexual dating sites also appear as a favoured environment for engaging in sexual short-term relationships.

We make the hypothesis that the possibility of initiating casual relationships outside the frame of one's social environment does not only facilitate encounters for sexual minority groups such as gay men, but also among heterosexual men and women. Given the significant social control exerted on female sexuality and the potentially transgressive nature of sexual relations for women outside the context of a stable relationship (Ambjörnsson 2007; Bäckman 2003; Bozon 2009), we believe that the anonymous environment of online dating sites also tends to facilitate women's engaging in heterosexual casual relationships. In this article, we thus seek to analyse more specifically to what extent online dating changes practices and norms regarding heterosexual female sexuality.

\section{The framing of site architecture}

As shown notably by Michel Bozon and François Héran (2006), not all social environments are meeting places and relationship initiation tends to be confined to certain spaces (bars, parties, university, etc.). In other words, dating has its own geography. Moreover, each context has a specific spatial and social organisation that frames practices and interactions as well as the resulting relationships (Bozon/Héran 2006; Deschamps/Gaissad 2008; Léobon/Frigault 2007). This leads Bruno Perreau (2008) to highlight the importance of taking into account the spatial context when analysing how sexual relationships are initiated.

Furthermore, recent studies on Internet use show that the architecture of Internet sites influences and largely frames user behaviour (Bergström 2011; Chaulet 2009; Ellison et al. 2006). More specifically, Dominique Cardon claims that, far from being a neutral mediating tool, the interface design of online platforms has a "performative effect" on usage (Cardon 2008: 104).

Drawing on these studies, the second and more global aim of this article is to investigate the constitution of heterosexual dating platforms. Rather than a mere medium, we suggest that these sites should be viewed as a social space and that it is an important goal to understand how their specific organisation frames practices in the domain of sexuality. This more general aim leads us to contextualise online dating and to proceed in a qualita-

3 Translation by the author of the article. 
tive in-depth analysis of the architecture of heterosexual online dating platforms. Thus, rather than limiting the study to an analysis of outcome - does heterosexual online dating lead to casual relationships? - the objective is also to give a more general picture of the conditions of this practice in the context of dating sites.

\section{Fieldwork}

The results presented in this article are primarily based on different forms of in-depth qualitative analysis.

During the autumn of 2008, we conducted a vast inventory of French-speaking online dating sites which lead to the identification of 1045 different platforms (Bergström 2011). The sites were accessed through the search engine Google.fr and the use of more than 300 different key words. The three month long inventory was not interrupted until a strong redundancy was observed in the search results, and although the sample is not random, we believe it to give a good indication of the general tendencies that characterise the French dating site field. Five hundred and fifty one of the listed sites had published contact information that permitted us to invite the web creators to participate in an online survey based on questions regarding targeting practices and member characteristics. Questionnaires were collected from 145 sites that were then object to case studies: the analysis of the survey results was articulated with a systematic study of the sites' functionalities (means of communication and profile information), design (colour scheme, imagery and graphics) and textual content. Eleven semi-structured face-to-face interviews were also conducted with creators of different types of platforms.

Moreover, 42 biographical face-to-face interviews were made with heterosexual online dating site users, ranging from 20 to 68 years of age, of which 24 were women and 18 men. The majority of the interviewees were recruited in contexts that were unrelated to online dating (i.e. such as universities) and the only criteria of selection was that they have used an online dating site. However, the interviewee group was composed in such a way to ensure diversity in terms of gender, social class and, to a lesser extent, age. We mainly recruited individuals who were up to 35 years old who, in turn, constitute the largest group of dating site users in France (Bajos/Bozon 2008). All interviews were systematically transcribed and coded with the software Nvivo by the author of this article.

\section{The field of French heterosexual dating sites}

\section{Two normative universes}

As showed in a former study, the notion of online dating sites refers to a vast and diverse web of different platforms. There are today more than eight hundred heterosexual dating platforms of various natures and sizes targeting the French population (Bergström 2011).

4 Out of the 1045 registered sites, 883 (84.5\%) target primarily the heterosexual population (Bergström 2011). 
Furthermore, our study showed that far from addressing the same social groups, an important number of French dating sites are "specialised" and target individuals through diverse criteria such as religion, ethnicity, occupation, cultural taste, political opinion, sexual practice, etc. Hence, only a third of the heterosexual sites correspond to what is commonly known of as "mainstream” sites (Bergström 2011).

However, despite this apparent variety, two distinct subcategories of platforms can easily be identified. Indeed, the field of French heterosexual online dating sites is largely structured by a normative and explicit opposition between sites supposedly conceived for relationships that are "serious" and sites intended for relationships that are not. The underlying normative frame corresponds to the social representation of two types of heterosexual intimate relations based on radically different premises, content and signification. Presence or absence of romantic feelings for the partner constitute an important criterion of categorisation; but just as important is the temporal aspect of the relationship. As showed notably by Sharman Levinson (2001), intimate relations are indeed primarily defined and categorised not in terms of affectivity but contingent on the amount of time between the first encounter and sexual intercourse as well as the overall length of the relationship. Thus, a relationship will be considered "serious" when it lasts and when it is not immediately sexual.

Dating site creators, by considering the search for these respective types of relationships to be two fundamentally different things, both in terms of process and general meaning but also with regard to the set of information needed to evaluate the potential partner, produce specific platforms for each type of partner search, and more generally create two radically opposed normative universes.

\section{Symbolic separation}

The two heterosexual site subcategories are qualified both by users and webmasters as "serious sites" versus "libertine sites". Due to the textual nature of digital environments, where social spaces are to a large extent constructed by words, the distinction between the two is first a difference in denomination. On the main page, the sites are explicitly designated as one or the other:

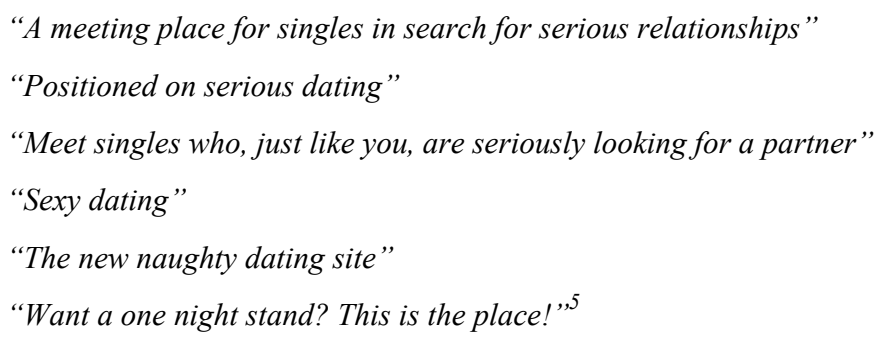

In addition to the verbal differentiation, the distinction between serious sites and libertine sites is realised through the main page setting and more specifically through a largely

5 Illustrative quotes from texts published on the main page of six different French heterosexual online dating sites. 
stereotypical interface design. These caricatured main pages, though seemingly lacking investment or attempt at originality, in fact constitute a fundamental instrument for the web creators to immediately communicate to what category the site belongs. The aim is indeed to minimise the ambiguity regarding the nature of the site through the creation of a coherent symbolic universe. Thus, the set of colours used is highly limited and recurrent within each subgroup. Whereas serious sites tend to use neutral colours like white and blue, libertine sites take recourse to colours associated with a feminine or affective universe, such as red, pink and purple. In the same way, the choice of images is characterised by clear tendencies. On their main page, serious sites publish photographs to a large extent composed by brown haired couples in light coloured clothes whereas lightly dressed blond or redhead women constitute a common subject of photographs used on libertine sites. Just as pictures used in publicity, both actors and relations are "hyper-ritualised" (Goffman 1987) with the aim of producing the right associations regarding the type of contacts that one can presumably expect from usage of the site.

Regarding the appearance, you need to have the cleanest frontage possible.

Question: How do you do that?

Well, for example, you can't have a picture... The picture on the main page, you can't have a super sexy girl in a string. It's for sure that that's going to attract guys, it's going to attract a certain type of guys. And somehow the girls are going to find themselves with those guys who are inclined to look for a one night stand. So, it's no good (...)

Question: How did you choose the photo? [i. e., the photo on the main page]

In fact, it's a very well-known photo... It's a brown head girl, we didn't pick a blond girl because that's too ostentatious. The guys, they'll [simulates excitement]. We wanted a pretty serious picture, so: a brown-haired girl, blue eyes.

[Webmaster of a serious site]

The extensive use of stereotypes also characterises the texts published on the main page. Serious sites largely take on a romantic discourse when presenting the site and its raison d'être: "Find your soul mate", "Find the love of your life", "Take on your best Romeo outfit and make your declaration of love under Juliette's balcony". A text analysis of the discourse used by the libertine sites clearly shows that these are conceived on an oppositional mode with the serious sites. The users and the relationships promoted are indeed described in terms of "free love", "liberated individuals", "nonconformist", "no moral limits", etc. Like the transgressive "exterior limits" defined in opposition to the "virtuous circle” conceptualised by Gayle Rubin (Rubin/Butler 2001), these sites are presented to the users as a social space for relationships that do not conform to hetero-normative ideals regarding decency.

\section{Functional differences}

In addition to the differentiation in design and discourse, the two heterosexual online dating subgroups also present different contents and services. When promoting a meeting place for potential long-term partners, the usage of the site is also conceived as a longer 
and more elaborate process. The specificity of the serious sites consists notably in privileging mail interaction rather than instant chat and, in the case of large established sites, in proposing detailed tests with the aim to evaluate the compatibility of potential partners. The apparent focus on questions regarding socio-professional status, life-style and cultural taste indicates that partner compatibility is to a large extent conceived as social homophily.

The primary difference between the two heterosexual site subgroups however concerns sexuality. Whereas sexual practice, together with physical appearance, constitutes an important part of the profile information given on libertine sites, this element is entirely absent on sites presented as destined for long-term relationships. In spite of the numerous and detailed questions aiming at "matching" future partners, one observes indeed an absence of information regarding sexual compatibility or preferences that reveals the inexpressible nature of this type of criteria in a heterosexual dating context aiming at being serious.

Chart 1: Tendencies in heterosexual site differentiation

\begin{tabular}{|c|c|c|}
\hline & "SERIOUS" SITES & "LIBERTINE" SITES \\
\hline \multicolumn{3}{|c|}{ Symbolic differentiation } \\
\hline Discourse & $\begin{array}{l}\text { Romantic } \\
\text { (true love, soul mate, serious...) } \\
\text { No sexual content }\end{array}$ & $\begin{array}{l}\text { Transgressive } \\
\text { (liberated, anti-conformist, without } \\
\text { limits...) } \\
\text { Sexually explicit }\end{array}$ \\
\hline Colours & Blue, white, grey & Pink, purple, red, black \\
\hline Imagery & $\begin{array}{l}\text { Couples, white, young, smiling, } \\
\text { brown haired, white clothing. }\end{array}$ & $\begin{array}{l}\text { Women, white, young, no smiling, } \\
\text { blond or red haired, lightly dressed, } \\
\text { dark clothing. }\end{array}$ \\
\hline \multicolumn{3}{|c|}{ Material differentiation } \\
\hline \multirow[t]{2}{*}{ Functionalities } & Mail & Chat \\
\hline & Compatibility tests & Webcam \\
\hline \multicolumn{3}{|l|}{ Profile questions } \\
\hline Number & Numerous & Sparse \\
\hline Content & $\begin{array}{l}\text { Socio-professional information and } \\
\text { cultural taste. No sexual information. }\end{array}$ & $\begin{array}{l}\text { Physical appearance and sexual in- } \\
\text { formation }\end{array}$ \\
\hline
\end{tabular}

A comparison with the French gay platforms gives an instructive perspective on the opposition between serious and unserious that characterises the heterosexual online dating field. Although one observes different kinds of gay sites that correspond to a distinction, and thus a categorisation, of different types of relationships, these are not conceived on a dichotomous mode. Rather than a dual distinction between sites for long-term and shortterm relations, gay sites commonly propose different "zones" for more or less sexually explicit communication. Named notably soft, hot and hard, the zones are proposed as a part of one and the same site which permits a back and forth movement depending on the users' momentary intent. Life-style and socio-professional information equivalent to that presented on heterosexual serious sites is mainly indicated in the soft zone, but appears next to explicit sexual information regarding the user. Also, as opposed to the heterosexual user, the member of a gay site has the possibility to indicate being simultaneously searching for a romantic relationship and sexual encounters. Thus, the sharp distinction 
and spatial separation of different dating universes has no equivalency in the field of French gay dating sites (Bergström 2011).

Meeting potential partners online and through sites specifically designed for this purpose is commonly seen as a radical change in the history of relationship formation (Cooper et al. 2000; Kaufmann 2006; Ross 2005). Pascal Lardellier, one of the first sociologists in France to have studied the usage of these sites, describes the phenomenon as a true Copernican revolution of dating norms and practices (Lardellier 2004). However, the qualitative analysis of the architecture of heterosexual dating platforms reveals a social space that is primarily structured by a stereotypical distinction between love and romanticism on one hand, and sexuality and transgression on the other hand. Independent of the usage ultimately made of these sites, one observes a setting that, far from being revolutionary, conveys largely traditional sexual norms. Moral respectability and normality as implicit sexuality confined to stable relationships is materialised through the radical opposition between serious and libertine sites. In other words, instead of challenging the traditional normative categorisation of intimate relationships, the field of heterosexual online dating sites "institutionalises" it through the creation of separate environments for either purpose.

\section{A reflection of female preference?}

In interviews with creators of serious online dating sites, the absence of sexual references and, more generally, the creation of a space presented as exclusively devoted to the formation of stable relationships, are largely described as an adaptation to the female users: The women are very important for us. It's this serious, general public [brand] positioning. It's for
serious dating. Meaning, you're not going to receive the... the information regarding the length of
the penis of the person who's talking to you [information presented on certain gay sites]. No, you're
going to be able to do something with your life. I mean, we primarily try to see to the need of the
women, you see. That's why we put a lot of importance to this... non pornographic positioning.

[Webmaster of a serious site]

At first sight, the female preference for long-term relationships and a non-sexual dating environment seems to be confirmed by the sex ratio on the serious and libertine sites. Indeed, questionnaires collected from 145 webmasters reveal that whereas the gender distribution tends to be balanced on the former, women represent only 10 percent of the total number of registered members on the libertine sites ${ }^{6}$. Also, a textual analysis of the online ads posted on a major serious site shows that, compared to women, men tend to declare more often to be searching for casual relationships (Bergström 2008). Similar observations have lead to the conclusion of a structural asymmetry and inadequacy between the

6 Due to the varying ways of counting users and also the sensitive nature of this information for the webmasters, these figures are to be interpreted with precaution. However, unlike the membership published by the sites themselves, the results of the questionnaire were anonymised and were thus seemingly less object to commercial strategies aiming at increasing the number of users. Also, when the effective number of members could be verified by accessing the member data base (6 sites), the observed figures were coherent with those indicated in the questionnaire. 
expectations of female and male users: whereas the majority of women would use online dating sites with the aim to find a "serious relationship", numerous male users would be looking for a "quick adventure" (Kaufmann 2006; Lardellier 2004).

However, to consider a declaration of intent as a direct reflection of preference is to suppose that the conditions and the consequences of such statements are the same for women and men. Yet, this is to neglect the gendered nature of sexual norms that renders women and men's access to sexuality largely unequal. To register onto a libertine site or to merely declare to be searching for a sexual encounter takes on a different meaning when the user is a woman.

\section{Image management}

It should be noted that the type of partner or relationship that one can declare be looking for on an online dating site depends on the censorship policies applied on the given platform. The control is particularly extensive on serious sites where a user risks having his or her profile deleted in case it contains sexually explicit contents. As illustrated by the following quotations, the webmasters preoccupation with keeping the sites free from sexual allusions is however not founded on an attempt to assure the "serious" nature of the contacts initiated on the platforms. Rather, the aim of the censorship policies is to create an atmosphere characterised by decency. In other words, these policies, but also the site architecture, design and discourse taken as a whole, do not primarily result from the webmasters' anticipation of actual usage. It is above all a question of creating and assuring a certain image of the site.

I wanted to have a very clean image. But then, people do whatever they want on their side. But a very clean image (...) Everything inside the site has to be very very clean!

Question: What do you mean, clean?

I mean that, whatever two consenting adults do outside of the site, it's not our business. But what they do inside the site, it's implicit [à demi-mots].

[Webmaster of a serious site]

Question: So you didn't want to use colours like that? [i..e., red and pink]

We're not at all... it's not a libertine site, you know! It's an online dating site for normal people, the general public, for people who want to build a life together, to start over, or to meet somebody. But then, it's like a car, people will use it their way... If you give them a car, a BMW, they might drive fast or they might not. In the end the driving depends on the driver (...) It's a serious site and at the same time it's still a dating site, so you can play around, it's fun. Maybe you come here for... for sex, well, in the end people do what they want. Or maybe you come here to find somebody, to get married, or to meet friends, well you're welcome. We just give them a framework.

[Webmaster of a serious site]

Indeed, the aim of the webmasters of serious sites is above all to "have a very clean image" that provides a "framework", independently of what the users do "on their side". The dichotomous opposition that structures the heterosexual online dating field is hence primarily a result of careful image management. The way a site is perceived is of great im- 
portance to the webmaster only to the extent that it is first and foremost an important issue for the users.

As all social spaces, the online environment potentially works as a "signifier" for the individuals that occupy it in the sense that it supposedly says something about them. As Erving Goffman pointed out, individuals draw conclusions regarding new acquaintances that depend notably on the context in which they meet them, assuming that "only individuals of a particular kind are likely to be found in a given social setting”, (Goffman 1959: 1). Thus, the site image appears as an important element of the users' self-presentation and the choice of site is important for what one comes across as being. However, what a certain social space "says" about an individual is partially determined by gender. This holds particularly true when the context is sexually explicit, and the relative disinterest for libertine sites shown by heterosexual women is also to be understood in this perspective. To register for such a site is perceived as a display of sexual availability, which for women implies a risk of sexual categorisation and stigmatisation. More than just a question of image, this has a concrete effect on their relative position in the future sexual relation:

In fact, I have the impression that, on that type of dating site [i.e.,libertine sites], since the presupposition is that... if you're there, it's because you're a slut, because it's for fucking. So, somehow it's like the thing with the prostitutes who get raped. You see? You're not going to be able to say "no", because you're there for that purpose. So, I think that's what worried me. It's the idea that, if you meet up with somebody and if ever you don't like him or if things turn wrong, you're going to be a bit trapped (...) You're going to have to go all the way because, because you're... You agreed and... and you did everything to show that you agreed, so you no longer have the right to say that you don't agree to it anymore.

[Sarah, user, 20 years old]

Sarah defines herself as a libertine and has had numerous experiences of casual encounters. Nevertheless, she qualifies the libertine site she registered for as "really dangerous" as she perceives that her mere presence on the site categorises her as a slut; a labelling that, in turn, induces a difficulty to refuse sexual intercourse. Her apprehension is based on former offline experiences where indeed, due to this stigma, she found herself forced to have sex. As the act of simply registering for a libertine site possibly per se defines her negatively, she never dared to meet up with somebody "in real life” and eventually signed out.

More generally, interviews with female dating site users clearly show that to declare to be looking for a "serious" relationship or to prefer serious sites to libertine sites can hardly be interpreted as mere expressions of preference and intent. Given the sexual norms that condition women's access to sexuality, it must also be understood as a strategic behaviour that aims to stave off potential negative categorisation. The romantic discourse and environment indeed function as a shield against such a stigma and thus create a situation where they can more freely negotiate long or short-term relationships. In other words, it enables women to more easily stay in control of the dating scenario and gives them a more favourable basis for negotiating the conditions for sexual intercourse.

This is the case of Alice (29 years old) who registered for a major French serious site with the intention to meet sexual partners. During a period of less than five months she had sexual encounters with over twenty different men. However, neither in her written self description nor during the conversation with potential partners did she make explicit the nature of the relationship that she was looking for. Knowing that such a behaviour 
could be considered "slutty" [sic], Alice takes on a romantic discourse and thus displays a respectable image that permits her to engage in a potentially transgressive behaviour while minimising the risks of negative categorisation and creating more leeway when negotiating the future relation. The implicit nature of sexual intent on serious sites is confirmed by Thomas, who also has met sex partners on such a platform. Moreover, he explains that if ever uttered, the information is coded:

It's never spelt out but a lot of girls put "carpe diem" in their ads and you kind of know that it's just another way of saying that they're open to an unserious thing.

[Thomas, user, 26 years old]

As highlighted by Alain Léobon and Louis-Robert Frigault, the anonymity facilitates the engagement in potentially stigmatised same-sex relations to the extent that it allows a relative disconnection between public identity and sexual practice (Léobon/Frigault 2004). For heterosexual women however, negative sexual categorisation does not only have an effect on their relations with the "outside world" but also on that with a sexual partner. Concerns regarding possible risks - presented as "security" issues - associated with meeting unknown men for possible relationships are present in almost all interviews with female users. These factors, as well as the strategies that derive from them, must be taken into account when one seeks to understand what women do, "want" and say on online dating platforms.

Aware of the impact that the image of the dating site has on the perception of the user, the webmasters institute two profoundly different types of spaces that correspond to the normative opposition between "serious" romantic relationships and "unserious" sexual relations. More specifically, and with the aim of attracting and pleasing female users, the webmasters of serious sites create an entirely asexual dating environment in line with a traditional representation of female sexuality. However, by confronting female users with a dual choice between spaces presented as moral and "clean" on one hand and spaces described in sexually transgressive terms on the other hand, they ultimately produce the very behaviour and "preference" that they anticipate. Indeed, due to the risk of stigmatisation (and ultimately physical harm) that, for women, comes with displaying explicit sexual intent, libertine sites are largely not used by heterosexual women, independently of the type of relationship they are searching for. Hence, the result of the sharp distinction found between serious and libertine sites is primarily the confinement of heterosexual women to a "romantic" dating environment where all types of sexually explicit content are either absent or censored. More generally, it thus appears important to consider the dating site field not as a mere indicator or reflection of the sexual norms that generally prevail in society, but as an important contemporary site of production (among others) of these very norms.

7 The Latin expression Carpe diem is commonly translated as "seize the day". 


\section{New dating scenarios}

The Internet today is an important "cruising”, venue for men who seek sexual encounters with other men and most gay sites are especially conceived to facilitate this activity. Online dating among the French heterosexual population on the other hand is principally located to websites largely framed by a romantic discourse and where the sexual dimension of dating is entirely absent. Nevertheless, far from resulting only in long-term relationships, serious dating sites constitute also an arena for short-term sexual relations. An online survey conducted in 2011 and advertised on 25 French online dating platforms showed that among the heterosexual users of the so called serious sites, a third had had the experience of a short-term sexual relationship with a partner met online (Bergström in press). Our interview material permits us to contexualise this hence frequent practice and shows that, compared to offline contexts and just as for the gay population, these sites constitute an environment that tends to facilitate such relationships.

\section{Temporality and "stories of reference"}

Although earlier qualitative studies on the use of online dating sites focus on the digital interface - and more specifically on the absence of face-to-face interaction and on the written communication -, we argue that this is not primarily the defining element that renders these sites specific in regard to other dating environments. What is profoundly new with online dating sites is the emergence of a space specialised in intimate relationship formation and frequented by a significant part of the population. This is worth highlighting not only because it differentiates dating platforms from other interactive Internet sites (online communities, forums, games, etc.) and other forms of mediated dating (e.g. matrimonial agencies and personal ads that represent a marginal social practice) but because it changes the very process of relationship formation.

Although ambiguity generally plays an important role in seduction and in dating (Bozon/Héran 2006), registering for a site specifically devoted to couple formation means $a$ priori to declare oneself single and in search of a partner. To render explicit this status notably results in an acceleration of the dating process. Whereas offline couple formation is often characterised by uncertainty and a vacillating progressively evolving approach, online dating is interacting with the initial "knowledge of the facts" and leads the actors to rather rapidly decide whether the relationship is to be or not.

Question: But what is it that's different on these sites? [i.e., a question regarding the process of couple formation]

I don't know, I think that... on the Internet... or rather in real life, it's a kind of game, you don't really know how it's going to end. Whereas maybe, on the Internet, when you meet [in real life], the dices are already thrown. When I met my boyfriend, given the conversations we'd had before, given everything we had talked about, I could guess that if he would be attracted to me and if I would be attracted to him, well we'd go out together. Whereas, when you meet somebody at a party, you don't

8 "Cruising" is an informal term, most often used by gay men, to refer to the act of searching for occasional, usually anonymous, sexual encounters in public spaces. 
really know. You try to know if he likes you, if you like him, etc. You might see each other, you might not, you might call each other etc. So, it's more of a bit-by-bit process. Whereas on the Internet you loose this whole kind of progressive dimension.

[Sandra, user, 23 years old]

The amount of time used for online interaction preceding a first meeting "in real life" varies. However, if there is affinity between the two potential partners, the first date is usually rapidly followed by the formation of the couple. Regarding her first offline meeting with her boyfriend, Sandra says that "nothing happened then, but he sent me an email afterwards saying 'So?' meaning 'so what do you think?'”. The first date indeed constitutes a decisive moment where the interlocutors decide whether to pursue the contact or not. If the appreciation is mutual, the absence of ambiguity regarding the underlying reasons of contact leads the relation to more rapidly take a physical and sexual form, compared to offline dating. Without considering the overall length of the relationship, one hence observes a new dating scenario that, due to the specificity of the dating environment, leads users to more rapidly engage in sexual relations.

Moreover, the interviews reveal how this accelerated scenario has an impact on the perception of both the resulting relationships and the dating sites as a meeting place. As already highlighted, temporality is an important variable for "making sense" of one's experience and for categorising and referring to other people's relationships. In particular, and as noticed by Michel Bozon, "to prolong the initial period of seduction implicitly states that one is ready to engage in a relatively long relationship" (Bozon 2009: 107). ${ }^{9}$ Inversely, to hasten sexual intercourse is generally perceived as a sign of the "unserious" nature of the relation. The accelerated dating process that comes with online dating leads the interviewees to consider the platforms as an environment above all propitious to "unserious" relationships.

You're gonna have to make a fundamental distinction between the person you pick up on Meetic [i. e., a major French dating site]; with whom you exchange three words, whom you meet up with in a café, whom you sleep with quickly and with whom it ends quickly. That's one type of story. And the other story, it's the person whom you meet on Facebook; whom you talk to, whom you invite to parties, whom you re-invite again to other parties, who invites you to parties, and you end up going out with her. And this can take one year. And you'll then have seen her a lot and during a long period of time before sleeping with her. Just because it's not an online dating site!

[Matthieu, user, 22 years old]

It didn't work out because I... because of this religion problem. We get along really well and all and we still call each other, but no. In the end, it's [i.e., the reason for ending the contact] also because we met, as I said before, through this site. It doesn't make me want to continue. It's strange to say so because you go on this site to meet somebody but in the end you say to yourself: "Well no, for me it can't be serious".

[Corinne, user, 21 years old]

Given the general image of dating sites, Corinne considers that a resulting relationship can per definition not be considered a "serious" one and that is one of the reasons why she

9 Translation by the author of the article. 
does not intend to pursue the initiated contact with her partner. The connection, seen also in Matthieu's comment, between specific meeting places, certain temporalities and anticipated outcomes is defined by Sharman Levinson as "stories of reference" (histoires de reference, cf. Levinson 2001). As ideal-typical dating scenarios, these function as a socially shared interpretative scheme that permits individuals to make sense of their experiences and to calibrate their expectations. Thus, "everyone knows" that one can generally expect an "unserious" relationship from an encounter in a discotheque, in a holiday resort or on an online dating site. In consequence, when Pauline (23 years old) registers on Meetic and engages in a short-term sexual relationship, she "really [has] the impression to have had the "Meetic experience"'”. Indeed, meeting online today has its own ideal-typical "story of reference". In other words, a socially shared script of what one can expect that tends to guide user conduct and, more importantly, produce self-fulfilling prophecies.

\section{The absence of peer audience}

Online dating sites appear as a context that favours sexual relationships for yet another and more important reason. Contrary to common meeting places both offline (bars, parties, university, work, etc.) and online (communities and social networks), the initial contact is taken outside one's social environment. Not only is the interlocutor exterior to the individual's social network, but the interaction takes place "behind closed doors". To the extent that the circle of friends exerts an important social control on the different phases of a relationship - from formation to dissolution -, the absence of peer audience has various effects as well.

The absence of a peer audience during the process of couple formation notably results in a generally weaker social regulation of the relationship. To be considered "being together" or "in a relationship" is not only up to the two partners but constitutes a status that is partly dependent on the confirmation of the social entourage that takes note of and acknowledges the relationship. Firstly, the specific nature of the relationship is only visible when manifested in a context where it demarks itself from other social relations. The interviewees define "going out together" primarily as the moment when the couple starts presenting itself as such in the public sphere: just as "coming out", "going out" is an act of public display. Hence the peer group plays an important role in instituting the couple. Secondly, as an observer of the relationship, the peer group also exerts control over its dissolution. Putting an end to a relationship is a delicate event not only due to emotional reasons but also because it is a statutory change that commonly has to be announced and answered for.

More commonly initiated without the peer group's knowledge, online relationships start off to a larger extent "in privacy". Before voluntarily rendering the relationship public and thus receiving the couple status, the frontiers between in and out of the relationship are largely permeable. Thus, if the use of online dating sites, more often than offline dating, results in sexual short-term relationships - meaning relations that both start and end rapidly -, this is also due to the weaker "institutionalisation" of the couple that results notably from the absence of the institutive-regulative role of the peer group. The casual character of these relations is therefore not necessarily intended a priori. 
Nevertheless, the short-term sexual relationships that result from online dating site usage are not a mere "effect of context". In the conducted interviews, especially with female users, sexuality appears subject to strategic management. The omnipresent risk of stigmatisation strongly conditions where, how and with whom women decide to engage in sexual relationships and makes dating sites indeed a favoured context for initiating such relations.

Question: What about the propositions a bit sexual that you received on Meetic or Facebook, did you reply, did you have any experiences...?

First, I always say no. But then, yeah, I've had experiences. Well, for example the second guy that I met on the site [i.e, Meetic]. But it wasn't, you know, a one night stand. We met several times, you see. But yeah... actually yes, I do have met people just for... Globally, I don't at all have one night stands in mind! I'm not at all like that! But then... then it's already happened that I don't get back to the person because I didn't like him. But originally, I'm not in that state of mind. But there's a lot of people who, yeah, have one night stands. And I don't do that because... often men... well, it's not even often, it's everyone; basically, there are two types of girls. There are the girls with whom they just want to have a bit of fun for a night. There's that category of girls there, and the others. And I really don't want to be a part of that category of girls (...) When I talk to people who I meet on the dating sites or elsewhere, I see that in the end the guys don't like those girls. But for one night, why not. So, they don't respect them. And I really watch out for that because when you say that a girl does that, you say she's a slut (...) The number of people I know that tell me they do that! They meet a girl one night, just like that, they do it that night and the next morning they wake up and they can't even touch the girl. She's a slut. "Good bye!"

[Corinne, user, 20 years old]

Later on in the interview, Corinne confirms that "in the end, [she has] had plenty of one night stands" but she firmly dislikes to define them as such since this puts her in the "wrong category" of unrespectable girls. Also, she really "watches out" for the circumstances under which she engages in sexual relations in order to prevent negative categorisation. For Corinne as well as for other interviewees online dating sites appear, as hypothesised, as an environment that facilitates casual relations to the extent that these relationships can take place without the social entourage being aware of it. More specifically, the anonymous environment permits women to engage in potentially transgressive practices while keeping up respectable appearances in the context of other social relations. Hence, online dating appears to come with social change in the domain of sexual practice but much less so in the domain of sexual norms. In consequence, the use of online dating sites is for women largely characterised by a distinction between what one says and what one does, in order to control what one comes out to be.

\section{Conclusion}

Although composed by a large number of various Internet platforms, the French heterosexual dating site field is largely structured by a normative opposition between "serious" and "unserious" relationships. As a consequence, one observes a new online sexual territory stereotypically subdivided between hypersexualised and hyperromanticised spaces. Moreover, due to the risk of negative sexual categorisation that comes with the display of 
sexual availability, the "libertine" sites are largely not used by women. As a consequence, the interviewees take recourse and recruit their sexual partners on sites applying a strict censorship on sexual contents and that more generally are marked by a normative framework where casual sex and moral respectability are opposed. To empirically determine the specific effect of the sites' social organisation on user conduct is difficult. However, it appears plausible that women's self-presentation strategies, which largely take on a romantic discourse even when searching for sexual encounters, are also influenced by the normative universe created by the serious sites. As articulated by one of the webmasters, they create a "framework" that, although far from determining user conduct, is imposed on the users and affects how these are perceived and, hence, how they present themselves.

Yet, as hypothesised, heterosexual online dating sites appear as a favourable context for casual relationships to the extent that the anonymity permits women to engage in such practices while minimising the associated risk of stigmatisation by the peer group. Moreover, the interviews reveal the importance of other factors favouring short-term sexual relationships. Searching for partners on dating sites is more generally linked with a new dating scenario. Due to the explicit stating of one's status as a single and in search of a relationship, and in the absence of the institutive-regulative institution of the peer group, the entrance to as well as the exit from sexual relations tend be more rapid than in offline dating. Thus, it should also be noted that what a posteriori can be defined as "casual dating" does not necessarily correspond to the initial intention of the users.

Far from being the "free and unstrained" sexual environment described by Alain Léobon in his study on gay internet sites, heterosexual online dating is characterised by largely traditional sexual norms both in regard to practice and the social organisation of the sites. The qualitative in-depth analysis does not reveal a straight "cruising area" or a major change of heterosexual dating norms, but rather the complex conditions of women's access to sexual relations. Although online dating sites appear indeed as a new sexual territory that favours casual relationships, it comes also with new normative boundaries. Future research will tell us whether the change observed in relation to practices will, in turn, transform what is considered acceptable sexual conduct for heterosexual women.

\section{References}

Ambjörnsson, F. (2007). I en klass för sig. Genus, klass och sexualitet bland gymnasietjejer [In a class of one's own. Gender, class and sexuality among high school girls]. Stockholm: Ordfront förlag.

Bäckman, M. (2003). Kön och känsla. Samlevnadsundervisning och ungdomars tankar om sexualitet [Gender and feelings. Sex education and young people's thoughts on sexuality]. Stokholm: Makadam.

Bajos, N. \& Bozon, M. (2008). Enquête sur la sexualité en France. Pratiques, genre et santé. Paris: La Découverte.

Benotsch, E., Kalichman, S. \& Cage, M. (2002). Men who have met sex partners via the Internet: Prevalence, predictors and implications for HIV prevention. Archives of Sexual Behaviour, 31, pp.177183.

Bergström, M. (in press). Nouveaux scénarios et pratiques sexuels chez les jeunes utilisateurs de sites de rencontres. Agora Débat/Jeunesse, 60 (accepted for publication in spring 2012).

Bergström, M. (2011). La toile des sites de rencontre en France. Topographie d'un nouvel espace social en ligne. Réseaux, 166, pp. 225-260. 
Bergström, M. (2008). Rencontres virtuelles et rapports de genre. La fréquentation des sites de rencontre par les étudiants en France. Paris: Sciences Po Paris (Master's thesis).

Bozon, M. (2009). Sociologie de la sexualité. Paris: Armand Colin.

Bozon, M. \& Héran, F. (2006). La formation du couple. Textes essentiels pour la sociologie de la famille. Paris: La Découverte

Brym, R. \& Lenton, R. (2001). Love online: A report on digital dating in Canada. Toronto: MSN (Research report).

Cardon, D. (2008). Le design de la visibilité. Un essai de cartographie du web 2.0. Réseaux 6, 152, pp. 93-137.

Chaulet, J. (2009). Sélection, appariement et modes d'engagement dans les sites de mise en relation. Réseaux, 154, pp. 131-164.

Cooper, A. (1998). Sexuality and the Internet: Surfing into the new millenium. In: CyberPsychology \& Behavior, 1,2, pp. 187-193.

Cooper, A., Boiez, S., Maheu, M. \& Greenfield, D. (2000). Sexuality and the Internet: The next sexual revolution. In: Szuchman, L.T. \& Muscarella, F. (Eds.), Psychological perspectives on human sexualitv. Wiley, New York, 2000, pp. 519-545.

Daneback, K. (2006). Love and sexuality on the Internet. Gothenburg: Göteborg University, Department of Social Work (Doctoral thesis).

Davis, M., Hart, G., Bolding, G., Sherr, L. \& Elford, J. (2006). E-dating, identity and HIV prevention: Theorising sexualities, risk and network society. Sociology of Health and Illness 28,4, pp. 457-478.

Deschamps, C. \& Gaissad, L. (2008). Pas de quartier pour le sexe? Le développement durable des rencontres sans lendemain. EchoGéo,5. http://echogeo.revues. org/4833 [retrieved: 2011-09-07].

Dutton, W., Helsper, E., Whitty, M., Buckwalter, G. \& Lee, E. (2008). Mate selection in the network society: The role of the Internet in reconfiguring marriages in Australia, the United Kingdom and United States. Conference paper for the forum “Meeting, dating, marriage, and the Internet”, Oxford Internet Institute, Oxford University, October $3^{\text {rd }}, 2008$.

Engler, K., Frigault, L-R., Léobon, A. \& Lévy, J. (2007). The sexual superhighway revisited. A qualitative analysis of gay men's perceived repercussions of connecting in cyberspace. Journal of Gay and Lesbian Social Services, 18, 2, pp. 3-37.

Ellison, N., Heino, R. \& Gibbs, J. (2006). Managing impressions online: Self-Presentation processes in the online dating environment. Journal of Computer-Mediated Communication, 11, pp. 415-441.

Fiore, A. \& Donath, J. (2004). Online personals: An overview. Conference paper for ACM ComputerHuman Interaction (CHI), Vienna, April 24 $4^{\text {th }}$ to $29^{\text {th }}, 2004$.

Goffman, E. (1987). Gender advertisements. New York: Harper Torchbooks.

Goffman, E. (1959). The presentation of self in everyday life. New York: Doubleday Anchor.

Hogan, B., Li, N. \& Dutton, H. W. (2011). A global shift in the social relationships of networked individuals: Meeting and dating online comes of age. Oxford: Oxford Internet Institute, Oxford University (Paper of the "Me, My Spouse and the Internet" project).

Illouz, E. (2006). Réseaux amoureux sur Internet. Réseaux, 138, pp. 269-272.

Kaufmann, J-C. (2006). La femme seule et le prince charmant. Paris: Armand Colin.

Kaufmann, J-C. (2007). La sociologie du couple. Paris: PUF.

Lardellier, P. (2004). Le cœur NET : Célibats et amours sur le web. Paris: Belin.

Léobon, A. \& Frigault, L-R. (2004). L'Internet gay: un nouveau territoire, face à une géographie des espaces de visibilité et de rencontre «en face à face». Paris: ANRS (Research report).

Léobon, A. \& Frigault, L.-R. (2007). La sexualité bareback: d'une culture de sexe à la réalité des prises de risque. In: Bozon M. \& Doré V. (Eds.), Sexualité, relations et prévention chez les homosexuels masculins. Un nouveau rapport au risque. Paris: ANRS, pp. 87-103 (Research report).

Levinson, S. (2001). Les "histoires de référence»: cadres socio-temporels et représentations des premières relations sexuelles. Paris: École des Hautes Études en Sciences Sociales (Doctoral thesis).

Liau, A., Millett, G., \& Marks, G. (2006). Meta-analytic examination of online sex-seeking and sexual risk behaviour among men who have sex with men. Sexually Transmitted Diseases, 33, pp. 576584. 
Madden, M. \& Lenhart, A. (2006). Online dating. Washington, DC: Pew Internet and American Life Project (Research paper).

Perreau B. (2008): Introduction. EchoGéo, 5. Paris. http://echogeo.revues.org/5923 [retrieved 2011-0425].

Ross, M. (2005). Typing, doing and being: Sexuality on the Internet. The Journal of Sex Research 42,4, pp. 342-352.

Rubin, G. \& Butler, J. (2001). Marché au sexe. Paris: EPEL.

Schulz, F., Skopek, J., Klein, D. \& Schmitz, A. (2008). Wer nutzt Internetkontaktbörsen in Deutschland? Zeitschrift für Familienforschung/Journal of Family Research 20, 3, pp. 271-292.

Tikkanen, R. \& Ross, M.W. (2003). Technological tearoom trade: Characteristics of Swedish men visiting gay Internet chat rooms. AIDS Education and Prevention 15, 2, pp. 122-132.

Velter, A. (2004). Enquête Presse Gay 2004. Paris: Institut de veille sanitaire.

Weatherburn, P., Hickson, F. \& Reid, D. (2003). Net benefits: gay men's use of the internet and other settings where HIV prevention occurs. London: Sigma Research (Research report).

Whitty, M. (2007). Revealing the 'real' me, searching for the 'actual' you: Presentations of self on an internet dating site. Computers in Human Behavior, 24, 4, pp. 1707-1723.

Submitted on/Eingereicht am: 18.04.2011

Accepted on/Angenommen am: 12.09.2011

Address of the author/Anschrift der Autorin:

Marie Bergström, M.A.

Ph.D. student in sociology

Observatoire sociologique du changement

Institut d'études politiques de Paris

27 rue Saint-Guillaume

75337 Paris Cedex 07

France/Frankreich

E-mail: marie.bergstrom@sciences-po.org 